\title{
MULTI RESPONSE CHARACTERISTICS OF PROCESS PARAMETERS DURING END MILLING OF GFRP USING GREY- BASED TAGUCHI METHOD
}

\author{
Reddy Sreenivasulu \\ RVR\&JC College of Engineering(Autonpmous) \\ Affliated to Acharya Nagarjuna University - India \\ E-mail: rslu1431@gmail.com
}

Submission: 10/10/2013

Accept: 21/10/2013

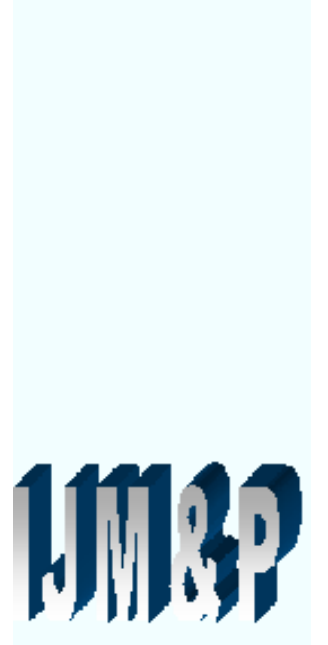

\section{ABSTRACT}

This paper deals with optimization of surface roughness and delamination damage on GFRP material during end milling using grey - based taguchi method. Three parameters namely spindle speed, feed rate and depth of cut were identified and ranges of the parameters for the present investigation were determined from preliminary experiments. Taguchi method based on L9 orthogonal array was selected and experiments were conducted as per experimental layout plan. The experiments were carried out on a CNC vertical machining center to perform $10 \mathrm{~mm}$ slots on GFRP work piece of $300 \mathrm{~mm} \times 50 \mathrm{~mm} \times 25 \mathrm{~mm}$ size by $\mathrm{K} 10$ carbide, four flute end milling cutter. Surface roughness and delamination damage were measured on each slot with the aid of form Talysurf 50 and tool maker's micro scope. An optimal combination of process parameters were obtained via grey based taguchi method. From the results of ANOVA, it is concluded that cutting speed and depth of cut are the most significant factors affecting the surface roughness and delamination damage factor and their contribution in an order of $26.84 \%$ and $40.44 \%$ respectively. A confirmatory experiment shows that $5.052 \mu \mathrm{m}$ for surface roughness and 1.682 delamination damage factor to validate the used approach after conducting with optimal setting of process parameters.

Keywords: GFRP, End milling, Grey- based Taguchi Method, ANOVA 


\section{INTRODUCTION:}

Fiber reinforced composite material are alternative to steel and other materials in highly corrosive industrial applications. In recent years, fiber reinforced composite material have been extensively used in variety of engineering applications in different fields such as Aerospace, Naval, and other industries. The machining of fiber reinforced composites is different from conventional materials. The behavior of composites is anisotropic.

The quality of machined products depends upon the type of fibers, reinforced materials used, bonding strength between fiber and matrix, type of weave, etc. Milling of composite materials is a rather complex task owing to the heterogeneity of the material and a number of other problems, such as surface roughness and delamination factor, which appear during the machining process and are associated with the characteristics of the material and the cutting parameters. Surface roughness and delamination factor are parameters that have a great influence on dimensional precision and performance of mechanical pieces.

For this reason, research and development have been carried out through design experiments to reach a specific surface roughness and a specific delamination factor. GFRP are increasingly being used for varieties of engineering applications because of their superior advantage over other engineering materials (BANNISTER, 2001). The advantages include high strength to weight ratio, high fracture toughness and excellent corrosion and thermal resistance. The tail arability of composites for specific applications has been one of their greater advantages and also one of the more perplexing challenges to adopting them as alternative to conventional materials (KISHORE; TIWARI; SINGH, 2009). Even though Glass fiber reinforce polymer (GFRP) pipe made by filament wind technique require further machining to facilitate dimensional control for easy assembly and control of surface quality for functional aspects (BHATNAGAR; RAMAKRISHNAN; NAIK; KOMANDURAI, 1995).

The users of FRP are facing difficulties when machining it, because basic knowledge and experience needed for conventional materials cannot be applied for such new innovative materials, whose ability to machine is different from that of 
INDEPENDENT JOURNAL OF MANAGEMENT \& PRODUCTION (IJM\&P)

conventional materials (MONTGOMERY, 1991). Thus it is desirable to investigate the behavior of FRPs during the machining process. Everstine and Rogers, (1971), predicted a new approach of an analytical theory of machining FRPs. In this study, they predicted a theory of plane deformation of incompressible composites reinforced by strong parallel fibers.

Bhatnagar et al (1995) studied how the fiber orientation influence both the quality of the machined surfaces and tool wear rate. The machinability of composites is influenced by the type of fiber inserted in the composites, and especially by the mechanical properties. On the other hand, the selection of parameters and tool are dependent on the type of fiber used in the composites and which is very important in the machining process. Davim, Mata (2004) revealed that the influence of cutting parameters on surface roughness in turning glass-fiber reinforced plastics using statistical analysis. Ramulu, et al (1994), experimentally carried out a study on machining of polymer composites and concluded that higher spindle speeds give better surface finish.

Santhana, krishanan et al (1989) studied the surface roughness on machining of GFRP composites, according to them, higher spindle speed produce more surface damage on the machined edge. This is attributed to higher cutting temperature, which results in local annealing of work material. They also focused on the machinability of FRP composites using the USM technique. According to Koing et al. (1985), measurement of surface roughness in FRP is less dependable compared to that in metals, because protruding fiber tips may lead to additional errors it may cause the fibers to stick on the stylus.

Palanikumar et al. (2006) studied the effect of cutting parameters on surface roughness on machining of GFRP composites by polycrystalline diamond (PCD) tool by developing a second order model for predicting the surface roughness average. Palanikumar et al (2008) developed a procedure to optimize the factors chosen to attain minimum surface roughness by incorporating response table and graph, normal plot, interaction plots, and analysis of variance technique. The average surface roughness of machined GFRP parts are important in manufacturing engineering applications which have considerable effect on some properties such as resistance to wear, reflection of light, transmission of heat, coating and fatigue 
INDEPENDENT JOURNAL OF MANAGEMENT \& PRODUCTION (IJM\&P)

http://www.ijmp.jor.br

v. 5, n. 2, February - May 2014.

ISSN: 2236-269X

DOI: 10.14807/iimp.v5i2.152

resistance. While machining, quality can be achieved through proper machining conditions. In order to know the quality of surface and dimensional accuracy in advance, it is necessary to adopt theoretical models making it feasible to do predict in the function of operation condition.

\section{EXPERIMENTAL SET UP:}

\subsection{Schematic of Machining:}

The work material used for present work is glass fiber reinforced polymeric composite material fabricated by hand layup method of $33 \%$ fiber and $66 \%$ general purpose resin with randomly oriented long fibers supplied by Saint Gobain Vetrotex India Limited. The dimensions of the work piece are $300 \mathrm{~mm} \times 50 \mathrm{mmX} 25 \mathrm{~mm}$. In this study, the experiments were carried out on a CNC vertical machining center (KENT and ND Co. Ltd, Taiwan make) to perform 10mm slots on GFRP work piece by K10 carbide, four flute end milling cutter as shown in Figure1.

Furthermore the spindle speed (rpm), the feed rate $(\mathrm{mm} / \mathrm{min})$ and depth of cut $(\mathrm{mm})$ are regulated in this experiment. Each experiment was conducted three times and the maximum width of the delamination damage (Wmax) around the slot periphery using Travelling Microscope with an accuracy of $10 \mu \mathrm{m}$ is measured at five places on each slot then average of them in $\mathrm{mm}$ after that Delamination Damage Factor calculated. Similarly, the surface roughness is measured at five places on each slot then average of them in $\mu \mathrm{m}$ is considered by a surface analyser of Form Talysurf 50 (Taylor Hobson Co Ltd). Measured observations are depicted in Table 3 and 4 .

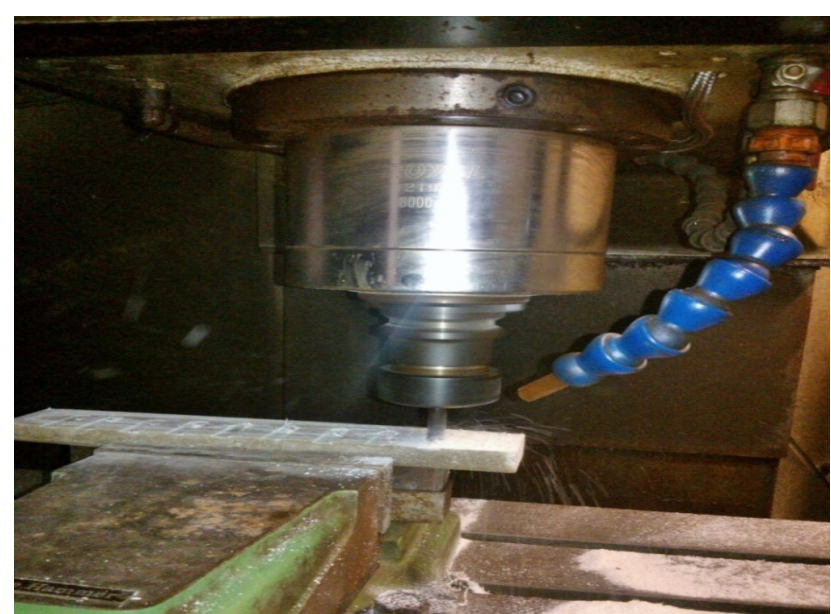

Figure 1: Machining of GFRP by CNC vertical machining center with $\mathrm{K} 10$ carbide End Mill 
INDEPENDENT JOURNAL OF MANAGEMENT \& PRODUCTION (IJM\&P)

http://www.ijmp.jor.br

v. 5, n. 2, February - May 2014.

ISSN: 2236-269X

DOI: 10.14807/iimp.v5i2.152

\subsection{Delamination and Surface Roughness and its Measurement}

Failure analysis of laminated composite structures has attracted a great deal of interest in recent years due to the increased application of composite materials in a wide range of high performance structures. Delamination, the separation of two adjacent plies in composite laminates, represents one of the most critical failure models in composite laminates. In fact, it is an essential issue in the evaluation of composite laminates for durability and delamination damage tolerance. The value of the delamination damage factor $\left(F_{d}\right)$ can be obtained using the following equation: $F_{d}$ $=\mathrm{W}_{\max } / \mathrm{W}$, Where $\mathrm{Wmax}$ is the maximum width of the damage around the slot periphery and $W$ is width of cut.

The surface roughness parameter used to evaluate surface roughness in this study is the Roughness average ( $\mathrm{Ra})$. This parameter is also known as the arithmetic mean roughness value, arithmetic average or centerline average. Within the presented research framework, the discussion of surface roughness is focused on the universally recognized $\mathrm{Ra}$. The average roughness is the area between the roughness profile and its Centre line, or the integral of the absolute value of the roughness profile height over the observed length.

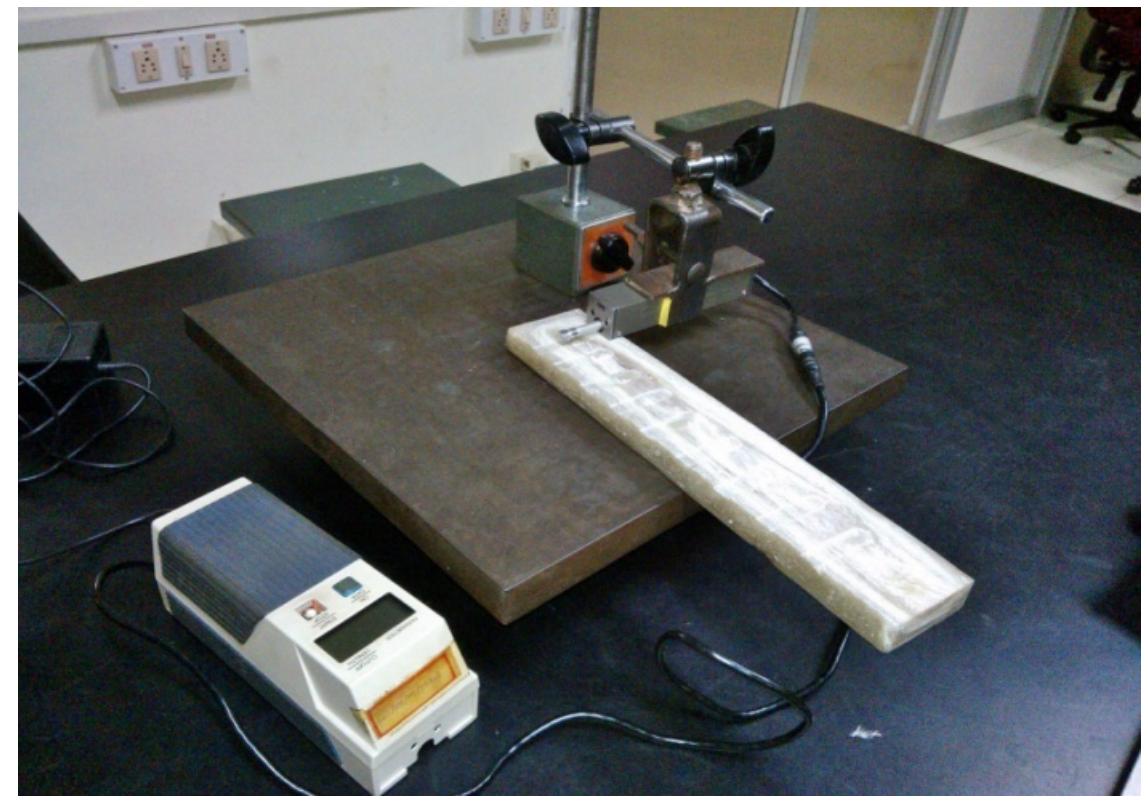

Figure 2: Measurement of surface roughness using Form Talysurf 50 (Taylor Hobson Co Ltd) 
INDEPENDENT JOURNAL OF MANAGEMENT \& PRODUCTION (IJM\&P)

http://www.ijmp.jor.br

v. 5, n. 2, February - May 2014.

ISSN: 2236-269X

DOI: 10.14807/iimp.v5i2.152

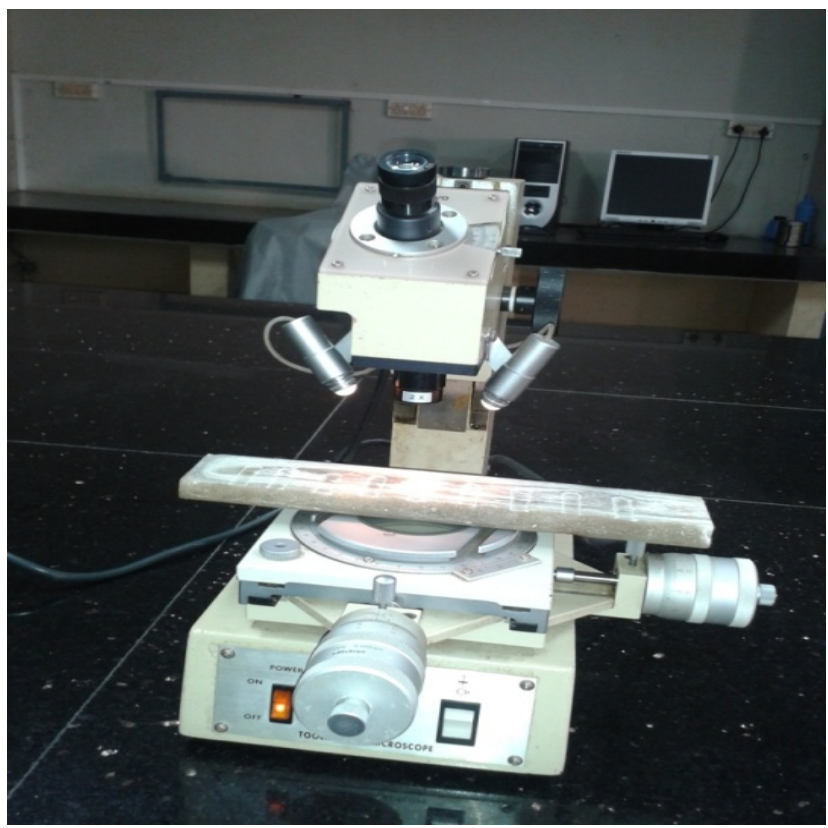

Figure 3: Measurement of delamination damage using Tool makers Microscope

\subsection{Experimentation as per Taguchi Design Method}

A plan of experiments based on Taguchi technique has been used to acquire the data. An orthogonal array and Grey relational analysis has been employed to investigate the cutting characteristics of GFRP material using $\mathrm{K} 10$ carbide tool. Finally, confirmation test (ANOVA) have been carried out to compare the predicted values with the experimental values confirm its effectiveness in the analysis of surface roughness and delamination damage. Also, The orthogonal array forms the basis for the experimental analysis in the Taguchi method. The selection of orthogonal array is concerned with the total degree of freedom of process parameters.

Total degree of freedom (DOF) associated with three parameters is equal to 6 $(3 \times 2=6)$. The degree of freedom for the orthogonal array should be greater than or at least equal to that of the process parameters. There by, a L9 orthogonal array having degree of freedom equal to $(9-1=8) 8$ has been considered .But in present case each experiment is conducted three times, therefore total degree of freedom $(9 \times 3-1=26)$ 26 has been considered finally. The machining parameters and their levels are given in table1. Plan of experiments based on Taguchi orthogonal array shown in table 4.

Table 1: Parameters and their Levels.

\begin{tabular}{llllll}
\hline Symbol & Factors & units & Level 1 & Level 2 & Level 3 \\
\hline A & cutting speed & $\mathrm{rpm}$ & 1000 & 1250 & 1500 \\
B & feed rate & $\mathrm{mm} / \mathrm{min}$ & 200 & 300 & 400 \\
C & depth of cut & $\mathrm{mm}$ & 0.5 & 1 & 1.5 \\
\hline
\end{tabular}

cc) (†) [http://creativecommons.org/licenses/by/3.0/us/]

Licensed under a Creative Commons Attribution 3.0 United States License 
INDEPENDENT JOURNAL OF MANAGEMENT \& PRODUCTION (IJM\&P)

http://www.ijmp.jor.br

v. 5, n. 2, February - May 2014.

ISSN: 2236-269X

DOI: 10.14807/iimp.v5i2.152

Table 2: Summary of observed experimental data (Surface Roughness):

\begin{tabular}{|c|c|c|c|c|}
\hline \multirow[t]{2}{*}{ Exp.No } & \multicolumn{3}{|c|}{ Surface Roughness } & \multirow{2}{*}{$\begin{array}{c}\text { Surface Roughness } \\
\text { average (Ra) } \mu \mathrm{m}\end{array}$} \\
\hline & Trial 1 & Trial 2 & Trial 3 & \\
\hline 1 & 2.600 & 2.640 & 2.650 & 2.630 \\
\hline 2 & 5.260 & 5.220 & 5.600 & 5.360 \\
\hline 3 & 3.800 & 3.730 & 3.900 & 3.810 \\
\hline 4 & 5.168 & 5.310 & 4.996 & 5.158 \\
\hline 5 & 2.106 & 3.021 & 1.071 & 2.066 \\
\hline 6 & 6.200 & 5.920 & 6.444 & 6.188 \\
\hline 7 & 3.260 & 3.860 & 2.678 & 3.266 \\
\hline 8 & 7.920 & 8.260 & 9.830 & 8.670 \\
\hline 9 & 3.850 & 3.786 & 3.920 & 3.852 \\
\hline
\end{tabular}

Table 3: Summary of observed experimental data (Delamination Damage Factor):

\begin{tabular}{ccccc}
\hline Exp.No & \multicolumn{3}{c}{ Delamination Damage Factor } & Average of Delamination \\
\cline { 2 - 4 } Damage Factor $\left(\mathbf{F}_{\mathrm{d}}\right)$
\end{tabular}

Table 4: Responses observed in the Experimentation as per Taguchi Design

\begin{tabular}{cccccc}
\hline Exp.No & \multicolumn{3}{c}{ Machining parameters } & \multicolumn{2}{c}{ Responses } \\
\cline { 2 - 6 } & $\begin{array}{c}\text { Cutting } \\
\text { Speed(A) } \\
\text { rpm }\end{array}$ & $\begin{array}{c}\text { Feed } \\
\text { rate(B) } \\
\mathrm{mm} / \text { min }\end{array}$ & $\begin{array}{c}\text { Depth of } \\
\text { Cut(C) } \\
\mathrm{mm}\end{array}$ & $\begin{array}{c}\text { Delamination } \\
\text { damage } \\
\text { Factor(Fd) }\end{array}$ & $\begin{array}{c}\text { Average Surface } \\
\text { Roughness(Ra) }\end{array}$ \\
$\mathbf{1}$ & 1000 & 200 & 0.5 & 1.22 & 2.630 \\
$\mathbf{2}$ & 1000 & 300 & 1 & 1.85 & 5.306 \\
$\mathbf{3}$ & 1000 & 400 & 1.5 & 1.24 & 3.810 \\
$\mathbf{4}$ & 1250 & 200 & 1 & 1.56 & 5.178 \\
$\mathbf{5}$ & 1250 & 300 & 1.5 & 1.47 & 2.066 \\
$\mathbf{6}$ & 1250 & 400 & 0.5 & 1.68 & 6.192 \\
$\mathbf{7}$ & 1500 & 200 & 1.5 & 1.51 & 3.266 \\
$\mathbf{8}$ & 1500 & 300 & 1 & 1.18 & 8.670 \\
$\mathbf{9}$ & 1500 & 400 & 0.5 & 1.12 & 3.852 \\
\hline
\end{tabular}

\subsection{Grey Relational Analysis}

In grey relational analysis, black represents having no information and white represents having all information. A grey system has a level of information between black and white. This analysis can be used to represent the grade of correlation between two sequences so that the distance of two factors can be measured discretely. In the case where experiments are ambiguous or when the experimental method cannot be carried out exactly, grey analysis helps to compensate for the 
INDEPENDENT JOURNAL OF MANAGEMENT \& PRODUCTION (IJM\&P)

http://www.ijmp.jor.br

v. 5, n. 2, February - May 2014.

ISSN: 2236-269X

DOI: 10.14807/iimp.v5i2.152

shortcoming in statistical regression .Grey relation analysis is an effective means of analyzing the relationship between sequences with less data and can analyze many factors that can overcome the disadvantages of statistical method.

\subsubsection{Data Pre-Processing}

In grey relational analysis, when the range of the sequence is large or the standard value is enormous, the functions of factors are neglected. However, if the factor goals and directions are different, the grey relational might produce incorrect results. Therefore, one has to pre-process the data which are related to a group of sequences, which is called 'grey relational generation'

Data pre-processing is a process of transferring the original sequence to a comparable sequence. For this purpose the experimental results are normalized in the range between zero and one. The normalization can be done form three different approaches.

If the target value of original sequence is infinite, then it has a characteristic of "the larger-the -better". The original sequence can be normalized as follows.

$$
x_{i}^{*}(k)=\frac{x_{i}^{0}(K)-\min x_{i}^{0}(K)}{\max x_{i}^{0}(K)-\min x_{i}^{0}(K)}
$$

If the expectancy is the smaller-the better, then the original sequence should be normalized as follows.

$$
x_{i}^{*}(k)=\frac{\max x_{i}^{0}(K)-x_{i}^{0}(K)}{\max x_{i}^{0}(K)-\min _{i}^{0}(K)}
$$

However, if there is a definite target value to be achieved, the original sequence will be normalized in the form.

$$
x_{i}^{*}(k)=1-\frac{\left|x_{i}^{0}(K)-x^{0}\right|}{\max x_{i}^{0}(K)-x_{i}^{0}}
$$

Or the original sequence can be simply normalized by the most basic methodology i.e., let the values of original sequence be divided by the first value of sequence

$$
x_{i}^{*}(k)=\frac{x_{i}^{0}(K)}{x_{i}^{0}(1)}
$$


INDEPENDENT JOURNAL OF MANAGEMENT \& PRODUCTION (IJM\&P)

http://www.ijmp.jor.br

v. 5, n. 2, February - May 2014.

ISSN: 2236-269X

DOI: 10.14807/iimp.v5i2.152

Where $x_{i}^{*}(k)$ is the value after the grey relational generation (data preprocessing), max $x_{i}^{0}(k)$ is the largest value of $x_{i}^{0}(k), \min x_{i}^{0}(k)$ is the smallest value of $x_{i}^{0}(k)$ and $x^{n}$ is the desired value.

\subsubsection{Grey relational coefficient and grey relational grade}

Following data pre-processing, a grey relational coefficient is calculated to express the relationship between the ideal and actual normalized experimental results. They grey relational coefficient can be expressed as follows:

$\zeta_{i}(k)=\frac{\Delta_{\min }+\zeta . \Delta_{\max }}{\Delta_{o i}(k)+\zeta . \Delta_{\max }}$

Where $\Delta_{o i}(k)$ is the deviation sequence of the reference sequence $x_{o}^{*}(k)$ and the comparability sequence $x_{i}^{*}(k)$, namely

$$
\begin{aligned}
& \Delta_{o i}(k)=\left\|x_{o}^{*}(k)-x_{i}^{*}(k)\right\| \\
& \Delta_{\max }=\max _{\forall j \varepsilon i} \max _{\forall k}\left\|x_{0}^{*}(k)-x_{i}^{*}(k)\right\| \\
& \Delta_{\min }=\min _{\forall j \varepsilon i} \min _{\forall k}\left\|x_{0}^{*}(k)-x_{i}^{*}(k)\right\|
\end{aligned}
$$

$\varsigma$ is distinguishing or identification coefficient $\varsigma \varepsilon$ to $[0,1] . \varsigma=0.5$ is generally used.

After obtaining the grey relational coefficient, normally choose the average of the grey relational coefficient as the grey relational grade. The grey relational grade is obtained by

$$
\gamma_{i}=\frac{1}{n} \sum_{k=1}^{n} \zeta_{i}(k)
$$

In the grey relational analysis, the grey relational grade shows the relationship among the sequences. If the two sequences are similar, then the value of grey relational grade is equal to 1 . The grey relational grade also shows the degree of influence of the comparability sequence over the reference sequence. If a particular comparability sequence is more important than the other sequences to the reference, then the grey relational grade for that comparability and reference sequence will be higher than other grey relational grades. 


\subsection{Analysis and discussion of Experimental results}

In the present study, surface roughness and delamination damage for different parameters and experimental runs are listed in table 2.typically, lower values of the surface roughness and delamination damage as the target values are desirable. Therefore, the data sequences have the smaller-the-better characteristic. The values of surface roughness and delamination damage are set to be the reference sequence. More over the results of 9 experiments were the comparability sequences $\mathrm{xi}^{*}(\mathrm{k}), \mathrm{i}=1-9, \mathrm{k}=1-3$.

Table 3 Response sequences after data pre processing

\begin{tabular}{|c|c|c|}
\hline $\begin{array}{l}\text { Comparability } \\
\text { sequence }\end{array}$ & $\begin{array}{l}\text { Surface Roughness } \\
\text { (Ra) }\end{array}$ & $\begin{array}{l}\text { Delamination Damage } \\
\text { Factor (Fd) }\end{array}$ \\
\hline 1 & 0.9146 & 0.8630 \\
\hline 2 & 0.5012 & 0.0000 \\
\hline 3 & 0.7359 & 0.8356 \\
\hline 4 & 0.5317 & 0.3972 \\
\hline 5 & 1.0000 & 0.5205 \\
\hline 6 & 0.3758 & 0.2328 \\
\hline 7 & 0.8182 & 0.4657 \\
\hline 8 & 0.0000 & 0.9178 \\
\hline 9 & 0.7295 & 1.0000 \\
\hline
\end{tabular}

Table 3 Lists all of the sequences following data preprocessing using equation(2) .Also, the deviation sequences $\Delta_{\mathrm{oi}}, \Delta_{\max (\mathrm{k})}$ and $\Delta_{\min (\mathrm{k})}$ for $\mathrm{i}=1-9, \mathrm{k}=1$ 3 can be calculated as follows.

$$
\begin{aligned}
& \Delta_{01(1)=\mid} x_{0}{ }^{*}(1)-x_{1}{ }^{*}(1)|=| 1.00-0.9146=0.0854 \mid \\
& \Delta_{01(2)=\mid} x_{0}{ }^{*}(2)-x_{1}{ }^{*}(2)|=| 1.00-0.8630=0.1370 \mid \\
& \Delta_{\max }=\Delta_{05}(1)=\Delta_{09}(2)=1.0000 \\
& \Delta_{\min }=\Delta_{08}(1)=\Delta_{02}(2)=0.0000
\end{aligned}
$$

The distinguishing coefficient $\zeta$ can be substituted for the grey relational coefficient in equation (5). If all the process parameters have equal weight then $\zeta$ is 0.5 . 
INDEPENDENT JOURNAL OF MANAGEMENT \& PRODUCTION (IJM\&P)

http://www.ijmp.jor.br

v. 5, n. 2, February - May 2014.

ISSN: 2236-269X

DOI: 10.14807/iimp.v5i2.152

Table 4: Grey relational coefficient and grade

\begin{tabular}{|c|c|c|c|}
\hline \multirow[t]{2}{*}{ Runs } & \multicolumn{2}{|c|}{ Grey Relational Coefficients } & \multirow{2}{*}{$\begin{array}{c}\text { Grey } \\
\text { Relational } \\
\text { Grade( } \Gamma)\end{array}$} \\
\hline & $\overline{(\mathrm{Ra})}$ & $(\mathrm{Fd})$ & \\
\hline 1 & 0.8541 & 0.7849 & 0.8195 \\
\hline 2 & 0.5006 & 0.3333 & 0.4169 \\
\hline 3 & 0.6543 & 0.7525 & 0.7034 \\
\hline 4 & 0.5163 & 0.4534 & 0.4848 \\
\hline 5 & 1.0000 & 0.5104 & 0.7552 \\
\hline 6 & 0.4447 & 0.3962 & 0.4204 \\
\hline 7 & 0.7333 & 0.4834 & 0.6083 \\
\hline 8 & 0.3333 & 0.8588 & 0.5960 \\
\hline 9 & 0.6489 & 1.0000 & 0.8244 \\
\hline
\end{tabular}

Table 4 lists the grey relational coefficient and grade for each experiment of the $L_{9}$ orthogonal array by applying equations (5) and (6).

According to the performed experiment design it is clearly observed from table 4 and fig (3) that the end milling process parameter setting of experiment no.9 has the highest grey relational grade. Thus the experiment 9 gives the best multiperformance characteristics among the 9 experiments. The response table of Taguchi method was employed here to calculate the average grey relational grade for each factor level. The procedure was to group the grey relational grades by factor level for each column in the orthogonal array and then to average them. Grey relational grades for factors $A \& B$ at level 1 can be calculated as follows.

$\Gamma(\mathrm{A}) 1=[0.8195+0.4169+0.7034] / 3=0.6466$

$\Gamma(B) 1=[0.8915+0.4848+0.6083] / 3=0.6375$

Using the same method, calculations were performed for each factor level and response table was generated, as shown in table5.

Table 5: Average Grey Relational Grade for Factor and Levels of the Experiment

\begin{tabular}{|c|c|c|c|}
\hline Factors & Spindle speed(A) & Feed rate $(B)$ & Depth of cut (C) \\
\hline $\begin{array}{c}\text { Levels } \\
\Downarrow\end{array}$ & & & \\
\hline 1 & 0.6466 & 0.6375 & 0.6881 \\
\hline 2 & 0.5534 & 0.5893 & 0.4992 \\
\hline 3 & 0.6762 & 0.6494 & 0.6879 \\
\hline
\end{tabular}


INDEPENDENT JOURNAL OF MANAGEMENT \& PRODUCTION (IJM\&P)

http://www.ijmp.jor.br

v. 5, n. 2, February - May 2014.

ISSN: 2236-269X

DOI: 10.14807/iimp.v5i2.152

\section{Main Effects Plot - Data Means for GRG}

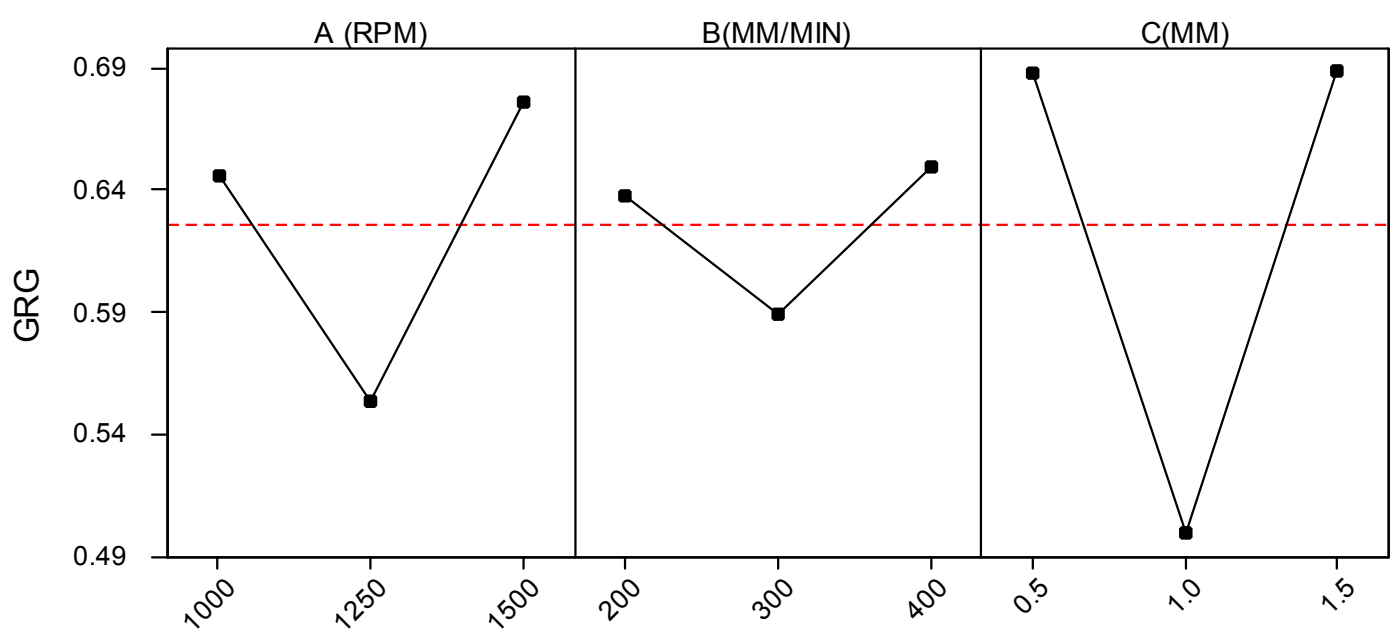

Interaction Plot - Data Means for GRG

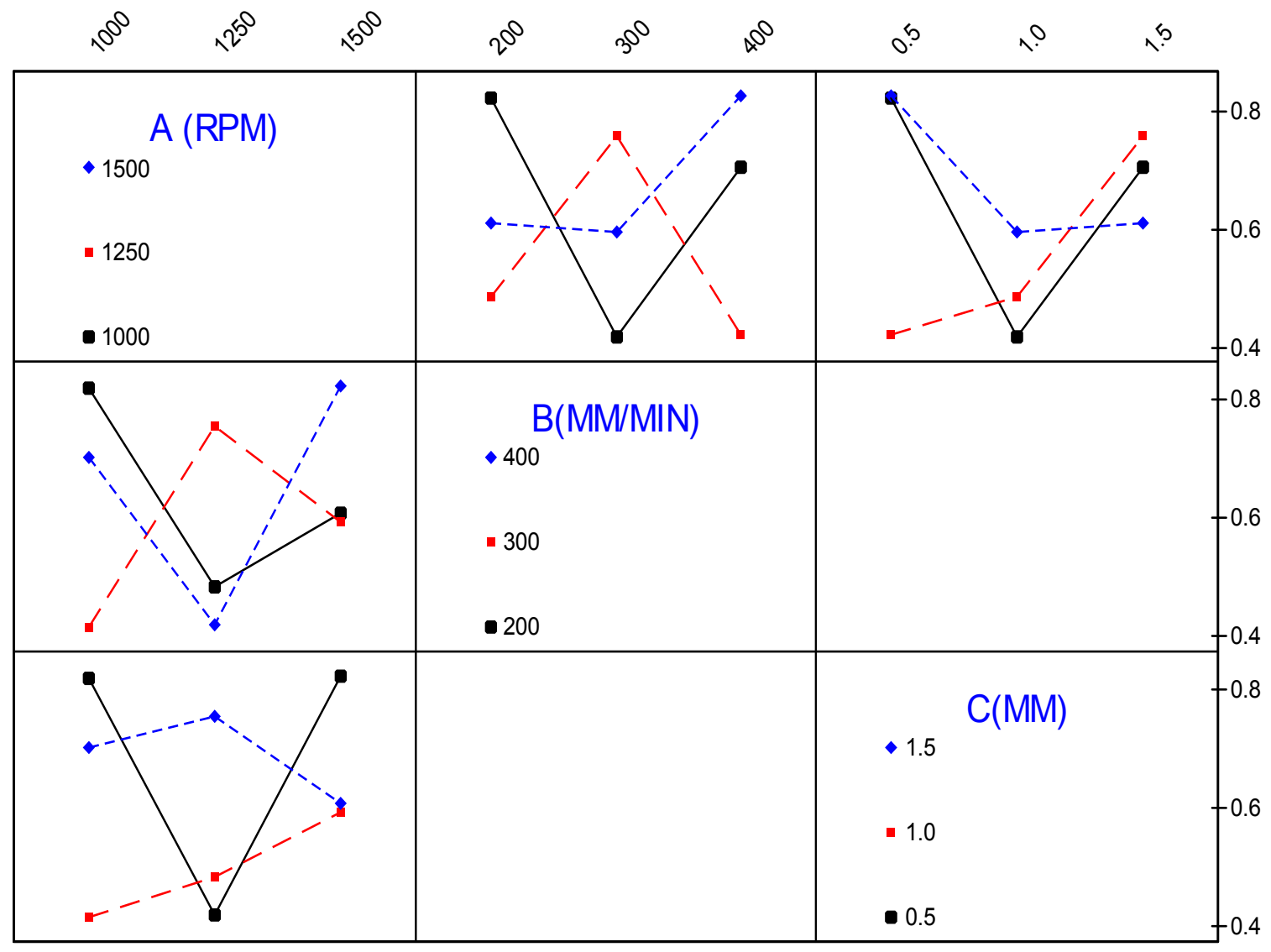


Table 6: ANOVA for Average Grey Relational Grade

\begin{tabular}{|l|l|l|l|l|l|l|}
\hline Symbol & $\begin{array}{l}\text { Cutting } \\
\text { Parameters }\end{array}$ & DOF & SS & MS & F & \\
\hline A & $\begin{array}{l}\text { Spindle } \\
\text { speed }\end{array}$ & 2 & 0.0372 & 0.0186 & $4.061^{*}$ & significant \\
\hline B & Feed rate & 2 & 0.0061 & 0.0130 & 2.838 & Insignificant \\
\hline C & Depth of cut & 2 & 0.0717 & 0.0358 & $7.816^{*}$ & significant \\
\hline Error & & 20 & 0.0916 & 0.00458 & & \\
\hline Total & & 26 & 0.2066 & & \\
\hline
\end{tabular}

The analysis of variance (ANOVA) of the experimental data was done to statistically analyze the multi response characteristics of the parameters under the experimental investigation. From Table 6 , it is observe that depth of cut has statistical and physically more significance $(78.16 \%)$, spindle speed has less significance $(40.61 \%)$ and feed rate has moderately less significance $(28.38 \%)$ obtained in end milling of GFRP with standard K10 carbide 4 flute end mill through grey-based taguchi method.

Table 7: Optimal values of individual machining characteristics

\begin{tabular}{|l|l|l|l|l|}
\hline Machining Characteristics & $\begin{array}{l}\text { Optimal } \\
\text { combination } \\
\text { of parameters }\end{array}$ & $\begin{array}{l}\text { Significant } \\
\text { parameters } \\
\text { (at 95\% } \\
\text { confidence } \\
\text { level) }\end{array}$ & $\begin{array}{l}\text { Predicted } \\
\text { optimum } \\
\text { value }\end{array}$ & $\begin{array}{l}\text { Experimental } \\
\text { value }\end{array}$ \\
\hline Surface Roughness (Ra) & A3B3C3 & A, C & $3.755 \mu \mathrm{m}$ & $3.824 \mu \mathrm{m}$ \\
\hline $\begin{array}{l}\text { Delamination Damage } \\
\text { Factor Fd ) }\end{array}$ & A3B3C3 & A, C & $1.251 \mathrm{~mm} / \mathrm{mm}$ & $1.178 \mathrm{~mm} / \mathrm{mm}$ \\
\hline $\begin{array}{l}\text { Average Grey Relational } \\
\text { Grade(GRG) }\end{array}$ & A3B3C3 & A, C & 0.8297 & 0.8244 \\
\hline
\end{tabular}

\section{CONCLUSIONS}

The machining characteristics of Glass Fiber Reinforced Polymeric composites have been studied. The primary machining characteristics such as surface roughness and delamination damage factor were studied for End milling. The results obtained from the experiments as follows.

- From average grey relational grade table, the combination of parameters having the values of, $0.5 \mathrm{~mm}, 1500 \mathrm{rpm}$ and $400 \mathrm{~mm} / \mathrm{min}$ are obtained for spindle speed, feed rate and depth of cut respectively for optimizing surface roughness and delamination damage. 
INDEPENDENT JOURNAL OF MANAGEMENT \& PRODUCTION (IJM\&P)

- From average grey relational grade table, depth of cut, spindle speed and feed rate are the order of influence of parameters (C1 A3 B3) on surface roughness and delamination damage during machining of GFRP.

- The result of ANOVA for average grey relational grade, spindle speed and depth of cut were most significant parameters for influencing surface roughness and delamination damage

- Finally, concluded that for end milling of GFRP composites to minimize surface roughness and delamination damage the parameters contributions in an order are $78.16 \%$ of depth of cut and $40.61 \%$ of spindle speed for influencing the observed responses.

\section{REFERENCES}

BANNISTER, M. (2001). Challenges for composites into the next millennium - a reinforcement perspective. Composites Part A: Applied Science and Manufacturing, v.32, n. 7, p. 901-910.

KISHORE, R. A.; TIWARI, R.; SINGH, I. (2009). Investigation of drilling in [(0/90)/0] s glass fibre reinforced plastics using taguchi method. Advances in Production Engineering and Manangement, v. 4, n. 1-2, p. 37-46.

BHATNAGAR, N.; RAMAKRISHNAN, N.; NAIK, N.K.; KOMANDURAI, R., (1995) On the machining of fiber Reinforced plastics (FRP) composite laminates, Int J.Machine Tool Manuf., v. 35, n. 5, p. 701-716.

MONTGOMERY, DC. (1991) Design and analysis of experiments. John Wiley and sons, NewYork

EVESTINE, G. C.;ROGERS. T. G, (1971) A Theory of machining of fiber reinforced materials, J. Comp. Mater, n. 5, p 94-105.

BHATNAGAR, N.; RAMAKRISHNAN, N.; NAIK, N. K.; KOMANDURAI, R., (1995), "On the machining of fiber Reinforced plastics (FRP) composite laminates", Int J. Machine Tool Manuf., v. 35, n. 5, p. 701-716.

DAVIM, J. P.; MATA, F. (2004) Influence of cutting parameters on surface roughness using statistical analysis. Indus Lubrication Tribol, v. 56, n. 5, p. 270-274.

RAMULU, M.; AROLA, D.; COLLIGAN, K. (1994) Preliminary Investigation on the surface Integrity of fiber Reinforced Plastics, Engineering systems Design and Analysis, ASME, v. 64, n. 2, p. 93-101.

SANTHANA KRISHANAN, G.; KRISHNAMOORTHY, R.; MALHOTRA, S. K. (1989) Machinability Characteristics of Fiber Reinforced Plastics Composites., JMWT., n. 17, p. 95-104.

KOING, W.; WULF, CH.; GRAB, P.; WILLERSCHEID, H. (1985) Machining of Fiber Reinforced Plastics, Annals of CIRP, n. 34, p. 537-548. 
INDEPENDENT JOURNAL OF MANAGEMENT \& PRODUCTION (IJM\&P)

http://www.ijmp.jor.br

v. 5, n. 2, February - May 2014.

ISSN: 2236-269X

DOI: 10.14807/iimp.v5i2.152

PALANIKUMAR, K.; KARUNAMOOTHY, L.; KARTHIKEYAN, R. (2006) Assessment of Factors Influencing Surface Roughness on the Machining of Glass Fiber-

Reinforced Composites, J. of Materials and Design, v. 27, n. 10, p. 862-871.

PALANIKUMAR, K. (2008) Application of Taguchi and Response surface

Methodology for surface Roughness In Machining Glass Fiber Reinforced Plastics by PCD Tooling, IJMPT, v. 36, n. 1-2, p. 19-27. 